\title{
New Distributional Records for Cardinalfishes (Perciformes/ Apogonidae) from North East Arabian Sea, Western Indian Ocean
}

\author{
Rajan Kumar $^{1}$ (D) A. P. Dineshbabu ${ }^{1} \cdot$ Ashok Kumar Jaiswar $^{2} \cdot$ Latha Shenoy $^{2} \cdot$ Annam Pavan Kumar $^{2}$. \\ Shikha Rahangdale ${ }^{1}$ - Vinaykumar Vase ${ }^{1}$. Divu Damodaran ${ }^{1}$
}

Received: 11 October 2018 / Revised: 16 March 2019 /

(C) Springer Nature Switzerland AG 2019

\begin{abstract}
Fishes of family Apogonidae popularly known as cardinalfishes are of high ecological importance owing to its trophic role. Though the presence of apogonids from the coastal waters of the northeastern Arabian sea are reflected in diets of predatory fishes of the region and bycatch of trawls, limited reports are available on species composition. Three species namely Apogonichthyoides pseudotaeniatus (Gon, 1986), Jaydia queketti (Gilchrist, 1903) and Jaydia lineata (Temmink \& Schlegal, 1842) have been reported for the first time from the region, adding to the apogonids diversity of the region. Ostorhinchus fasciatus (White, 1790) is also reported for the first time from the coastal waters of Gujarat. Morphometric assessment of the four species revealed several discriminating attributes capable of separating the species from each other.
\end{abstract}

Keywords North east Arabian Sea $\cdot$ Gujarat $\cdot$ Apogonids $\cdot$ Trawl $\cdot$ Bycatch

\section{Introduction}

Fishes of family Apogonidae popularly known as cardinal fishes are small percoid fishes mostly of size less than $120 \mathrm{~mm}$. They are basically coastal residents of coral, rocky reefs and adjacent habitats. They are among the few groups of marine fishes exhibiting oral egg brooding by males. The members of the family Apogonidae are characterized by moderately compressed, oval to elongate body with large prominent eyes comparable to snout length in size. They possess double-edged pre-opercle and have two dorsal fins with the first one having VI-VIII spines. The second dorsal fin has I spine and 8-14 soft rays. Anal fin of the species has two rigid spines and 8-18 soft rays (Gon 1986 and Allen 1999). The family enjoys wide distribution across temperate and tropical coastal waters of Indian, Pacific and Atlantic Ocean. The family is represented by 352 extant species belonging to 41 genera globally (Froese and Pauly 2018). As many as 65

Rajan Kumar

rajan.kumar@icar.gov.in

1 Indian Council of Agricultural Research-Central Marine Fisheries Research Institute, Kochi 682018, India

2 Indian Council of Agricultural Research-Central Institute of Fisheries Education, Mumbai 400061, India species belonging to 17 genera have been recorded from Indian waters (Saravanan et al. 2017) but most of them have been either recorded from reef ecosystem of Gulf of Mannar, Lakshadweep and Andaman and the Nicobar Islands or limited to east coast of India (Bay of Bengal) and southwest coast of India (Jones and Kumaran 1980; Dutt and Rao 1980; Suresh 2007; Hashim et al. 2012; Rajan etal. 2013; Muddulakrishna etal.2015; Ranjith etal. 2016a, b; Joshi et al. 2016; Saravanan et al. 2017).

The role of apogonids in the trophic structure is believed to be much higher than their relative abundance especially in reef systems (Marnane 2001). The ecological significance of the group warrants regions wise studies on diversity and abundance, to begin with in order to explore its ecological role in a specific system. The presence of apogonids from the area is regularly reflected in previous reports specially in context of diet composition of bottom-dwelling predatory fishes or bycatch of trawl fishery (Zynudheen et al. 2004; Metar et al. 2005; Saker et al. 2013; Mali et al. 2017; Dash et al. 2018). The current investigation on the trawl Low valued Bycatch (LVB) diversity along Gujarat coast reveal the presence of four species of apogonids in the region namely Apogonichthyoides pseudotaeniatus (Gon, 1986), Jaydia queketti (Gilchrist, 1903); Jaydia lineata (Temmink \& Schlegal, 1842) and Ostorhinchus fasciatus (White, 1790). The present study not only ascertains the presence of the species in the region but also help field enumerators in prompt reporting of the species. 


\section{Materials and Methods}

Specimens of A. pseudotaeniatus $(n=3), J$ queketti $(\mathrm{n}=3)$, $J$. lineata $(\mathrm{n}=3)$ and $O$. fasciatus $(\mathrm{n}=3)$ were collected from trawlers operated from Veraval and Mangrol fish landing centers (Fig. 1) of Gujarat as a part of species diversity studies of low-value bycatch (LVB) or trash landed by trawlers. One specimen each of $A$. pseudotaeniatus (MBM/P/T/A.21), J. queketti (MBM/P/T/A.22), J. lineata (MBM/P/T/A.23) and $O$. fasciatus (MBM/P/T/A.24) is preserved and maintained at Marine Biodiversity Museum of Veraval Regional Centre of Central Marine Fisheries Research Institute, Gujarat for future reference. The sites of capture based on GPS record of fishing boats were presented in a map (Fig. 1). The specimens were identified based on characters and keys presented in Gon (1986) Allen (1999) and Psomadakis et al. (2015). The morphometric measurements were recorded using digital calipers (to the nearest of $0.01 \mathrm{~mm}$ ). The morphometric measurements, meristic counts and terminology follow Hubbs and Lagler (1958). The morphometric variables were transformed into ratios to facilitate size independent comparison. An analysis of variance (ANOVA) has been in wide use for species discrimination (Devi et al. 2018; Kumar et al. 2018; Vikas et al. 2018) and hence was performed to analyze the difference between the species. A conservative level of significance (1\%) is used as sample size is limited. The meristic counts were taken under a dissection microscope. A short description of newly recorded species and a field key for all reported species from the study area provided to facilitate easy field identification.
Fig. 1 Map depicting fish landing centre and location of capture (V-Veraval fish landing centre; M-Mangrol fish landing centre; green icons-A. pseudotaeniatus; red icons-J. queketti; blue icons-J. lineata; yellow icons-O. fasciatus [Courtesy: Google Earth]

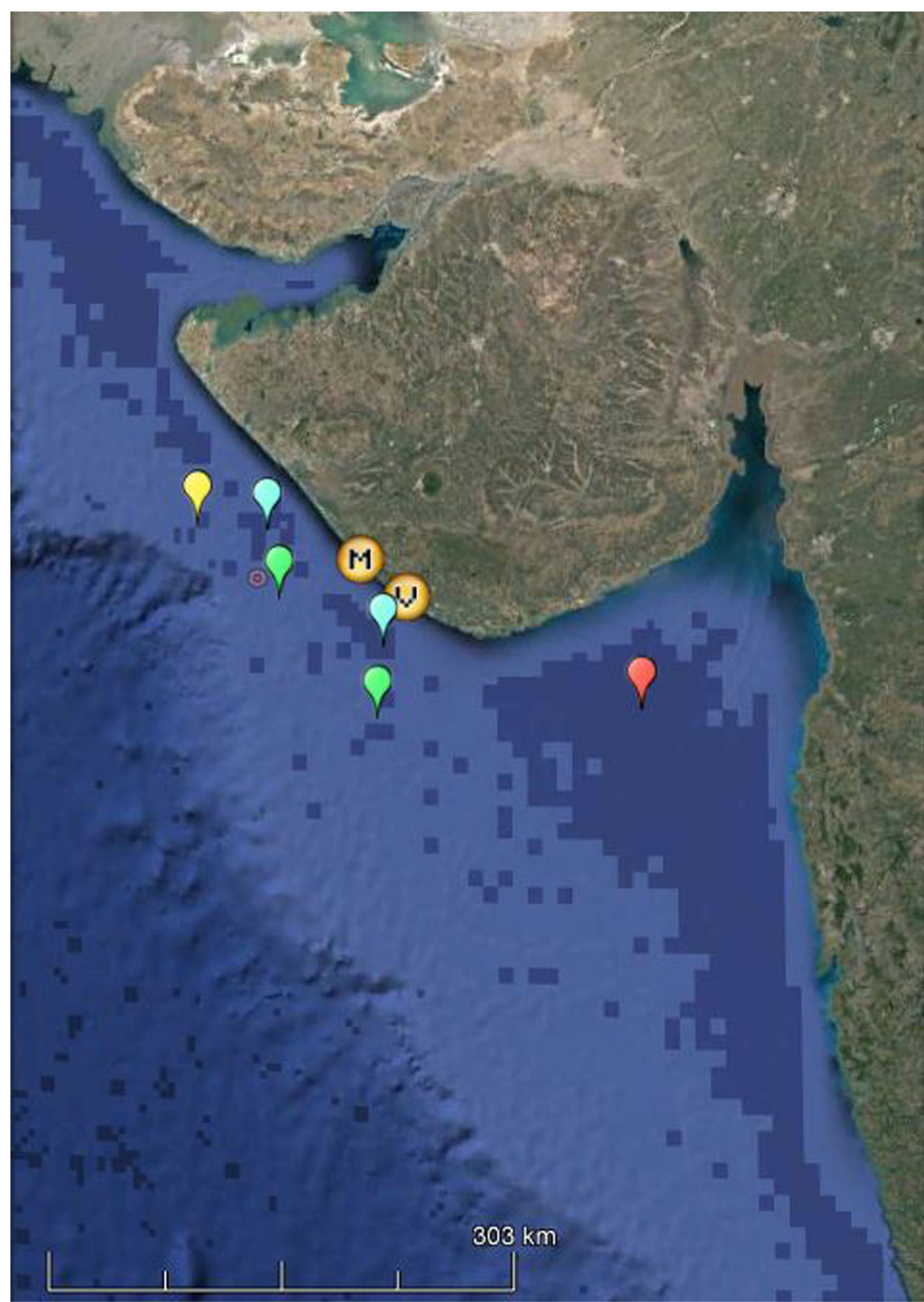




\section{Results and Discussion}

\section{Systematics}

A. Genus: Apogonichthyoides Smith, 1949

Species: Apogonichthyoides pseudotaeniatus (Gon, 1986) (Fig. 2)

Two specimens (126.13 \& $143.45 \mathrm{~mm}$ TL) and one specimen (138.02 cm TL) collected from trawl bycatch landed at Veraval and Mangrol fish landing centers of Gujarat respectively during October 2017 to September 2018.

Body oblong and relatively deeper; depth at 1st dorsal fin origin 41.1-44.8\% of standard length: pre-orbital length marginally smaller than eye diameter; pre-orbital length and eye diameter $7.2-8.5 \%$ and $11.5-12.9 \%$ of standard length respectively; colour brown to blackish brown; two dark transverse band at 1 st and 2 nd dorsal fin origin; a black blotch or spot at caudal (clearly visible in fresh specimen); dorsal, pelvic and anal fins dusky or dark.

\section{Distribution in Western Indian Ocean}

The Persian Gulf and the Gulf of Oman along northwestern boundary of western Indian Ocean (Froese and Pauly 2018); Pakistan along Northern Arabian Sea (Psomadakis et al. 2015); Off Kerala coast along South East Arabian Sea; off Gujarat Coast along northeast Arabian sea (present study; Fig. 1)

B. Genus: Jaydia Smith, 1961

Species: Jaydia queketti (Gilchrist, 1903) (Fig. 3)

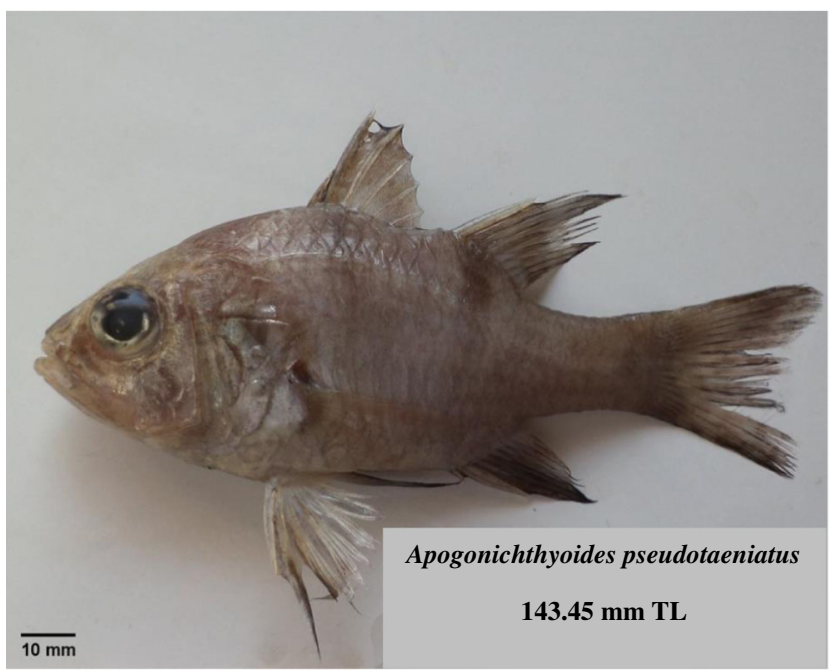

Figure 2 Apogonichthyoides pseudotaeniatus collected from Veraval fish landing centre, North west coast of India

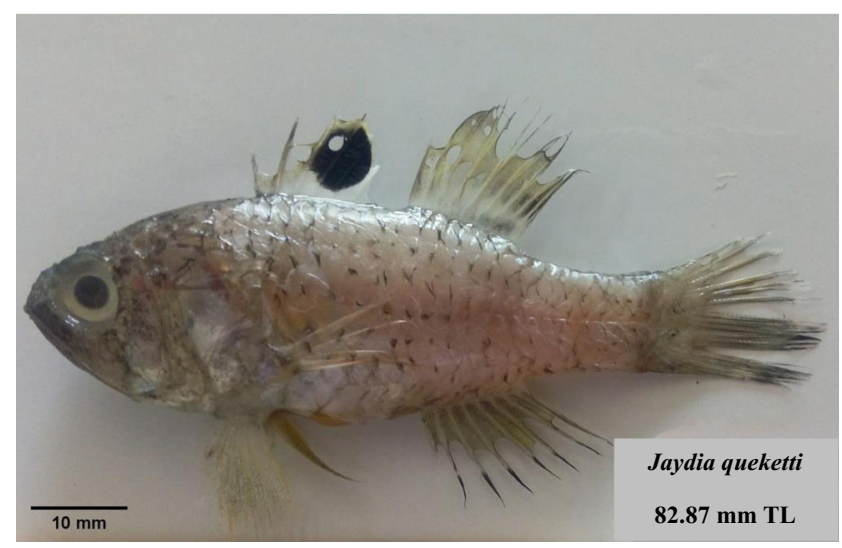

Fig. 3 Jaydia queketti collected from Veraval fish landing centre, North west coast of India

Three specimens $(82.22,82.87 \& 83.88 \mathrm{~mm}$ TL) collected from trawl bycatch landed at Veraval fish landing center of Gujarat during October 2017 to September 2018.

Body narrower with slight lateral compression; depth at $1 \mathrm{st}$ dorsal fin origin $35.1-36.1 \%$ of standard length: pre-orbital length much smaller than eye diameter; pre-orbital length and eye diameter 5.4-6.3\% and 9.2-10.1\% of standard length; colour slivery grey to light pinkish; scales on sides with black spots; prominent eyespot on posterior half of first dorsal fin; anal and caudal fins with dark margins.

\section{Distribution in Western Indian Ocean}

Southeast Africa; Persian Gulf and Gulf of Oman along western boundary of western Indian Ocean (Froese and Pauly 2018); Pakistan along Northern Arabian Sea (Psomadakis et al. 2015); Off Karnataka coast along southeast Arabian Sea (Saravanan et al. 2017); off Gujarat Coast along northeast Arabian sea (present study; Fig. 1)

Species: Jaydia lineata (Temmink \& Schlegal, 1842) (Fig. 4)

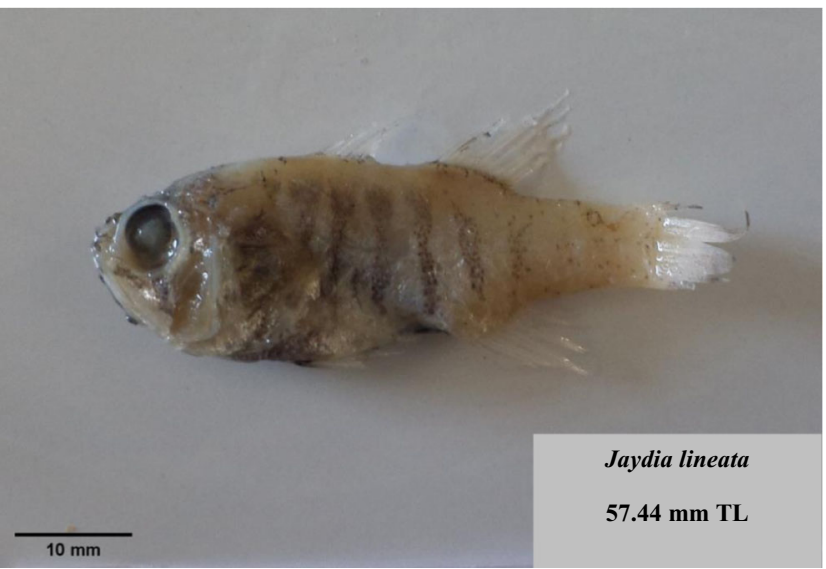

Fig. 4 Jaydia lineata collected from Mangrol fish landing centre, North west coast of India 


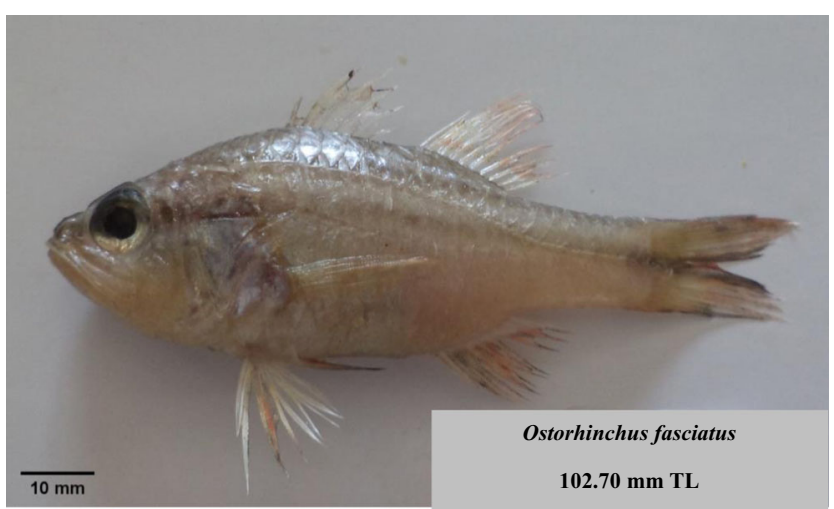

Fig. 5 Ostorhinchus fasciatus collected from Mangrol fish landing centre, North west coast of India

One specimen (57.20 mm TL) and two specimens ( $57.44 \&$ $58.35 \mathrm{~mm}$ TL) collected from trawl bycatch landed at Veraval and Mangrol fish landing centers of Gujarat respectively during October 2017 to September 2018.

Body narrower and laterally compressed; depth at 1 st dorsal fin origin 36.7-37.2\% of standard length: pre-orbital length much smaller than eye diameter; pre-orbital length and eye diameter $4.4-4.8 \%$ and $11.8-12.0 \%$ of standard length; slivery to sandy grey; ten to twelve dark transverse bands on sides of the body; dorsal and caudal fin margins slightly dusky.

\section{Distribution in Western Indian Ocean}

Gulf of Oman and Reunion Island along Eastern part of Western Indian Ocean; off Gujarat Coast along northeast Arabian Sea (present study; Fig. 1)

C. Genus: Ostorhinchus Lacepede, 1802

Species: Ostorhinchus fasciatus (White, 1790) (Fig. 5)

Three specimens $(62.15,102.70 \& 103.20 \mathrm{~mm}$ TL) collected from trawl bycatch landed at Veraval fish landing center of Gujarat during October 2017 to September 2018.

Body narrow and torpedo shaped; depth at 1st dorsal fin origin $31.2-39.0 \%$ of standard length: pre-orbital length
Table 1 Descriptive statistics and results of ANOVA for morphometric variables and meristic counts of four apogonid species from NE Arabian Sea

\begin{tabular}{|c|c|c|c|c|c|}
\hline Variables & O. fasciatus & J. queketti & J. lineata & A. pseudotaeniatus & $\begin{array}{l}\text { F- } \\
\text { value }\end{array}$ \\
\hline TL (Range) & $62.15-103.20$ & $82.22-83.88$ & $57.20-58.35$ & $126.13-143.45$ & - \\
\hline SL (Range) & $49.34-82.85$ & $63.64-65.06$ & $46.52-48.86$ & $100.38-113.03$ & - \\
\hline \multicolumn{6}{|c|}{$\%$ of SL $($ Mean \pm Std. dev) } \\
\hline $\mathrm{PD}_{1} \mathrm{~L}$ & $0.379 \pm 0.0052^{\mathrm{bc}}$ & $0.362 \pm 0.0053^{\mathrm{c}}$ & $0.382 \pm 0.0079^{\mathrm{b}}$ & $0.433 \pm 0.0166^{\mathrm{a}}$ & $28.49^{*}$ \\
\hline $\mathrm{PD}_{2} \mathrm{~L}$ & $0.593 \pm 0.0039^{\mathrm{b}}$ & $0.601 \pm 0.0019^{\mathrm{b}}$ & $0.601 \pm 0.0102^{\mathrm{b}}$ & $0.654 \pm 0.0029^{\mathrm{a}}$ & $72.50^{*}$ \\
\hline PAL & $0.648 \pm 0.0113^{\mathrm{b}}$ & $0.650 \pm 0.0069^{\mathrm{b}}$ & $0.644 \pm 0.0149^{\mathrm{b}}$ & $0.683 \pm 0.0094^{\mathrm{a}}$ & $08.04 *$ \\
\hline PPeL & $0.337 \pm 0.0055^{\mathrm{bc}}$ & $0.324 \pm 0.0020^{\mathrm{b}}$ & $0.353 \pm 0.0096^{\mathrm{ac}}$ & $0.372 \pm 0.0269^{\mathrm{a}}$ & $06.01 *$ \\
\hline PPecL & $0.395 \pm 0.0104^{\mathrm{a}}$ & $0.414 \pm 0.0055^{\mathrm{a}}$ & $0.391 \pm 0.0071^{\mathrm{a}}$ & $0.401 \pm 0.0209^{\mathrm{a}}$ & 01.96 \\
\hline HL & $0.364 \pm 0.0058^{\mathrm{a}}$ & $0.381 \pm 0.0078^{\mathrm{a}}$ & $0.373 \pm 0.0056^{\mathrm{a}}$ & $0.393 \pm 0.0217^{\mathrm{a}}$ & 03.17 \\
\hline $\mathrm{D}_{2} \mathrm{FL}$ & $0.149 \pm .0 .0072^{\mathrm{a}}$ & $0.186 \pm 0.0062^{\mathrm{b}}$ & $0.144 \pm 0.0007^{\mathrm{a}}$ & $0.134 \pm 0.0136^{\mathrm{a}}$ & $22.88^{*}$ \\
\hline AFL & $0.140 \pm 0.0087^{\mathrm{b}}$ & $0.177 \pm 0.0045^{\mathrm{c}}$ & $0.152 \pm 0.0076^{\mathrm{b}}$ & $0.123 \pm 0.0090^{\mathrm{a}}$ & $26.74 *$ \\
\hline $\mathrm{D} @ \mathrm{D}_{1} \mathrm{~F}$ & $0.362 \pm 0.0436^{\mathrm{b}}$ & $0.357 \pm 0.0049^{b}$ & $0.370 \pm 0.0029^{\mathrm{b}}$ & $0.430 \pm 0.0187^{\mathrm{a}}$ & $06.07 *$ \\
\hline $\mathrm{D} @ \mathrm{AF}$ & $0.316 \pm 0.0239^{\mathrm{b}}$ & $0.318 \pm 0.0023^{\mathrm{b}}$ & $0.304 \pm 0.0011^{\mathrm{b}}$ & $0.363 \pm 0.0072^{\mathrm{a}}$ & $12.93 *$ \\
\hline PrOL & $0.075 \pm 0.0076^{\mathrm{a}}$ & $0.057 \pm 0.0054^{\mathrm{c}}$ & $0.046 \pm 0.0022^{\mathrm{b}}$ & $0.078 \pm 0.0067^{\mathrm{a}}$ & $20.32 *$ \\
\hline ED & $0.105 \pm 0.0069^{\mathrm{b}}$ & $0.098 \pm 0.0046^{\mathrm{b}}$ & $0.119 \pm 0.0010^{\mathrm{a}}$ & $0.123 \pm 0.0072^{\mathrm{a}}$ & $13.48^{*}$ \\
\hline $\begin{array}{l}\text { First Dorsal fin } \\
\text { rays }\end{array}$ & VII & VII & VII & VII & - \\
\hline $\begin{array}{l}\text { Second Dorsal fin } \\
\text { rays }\end{array}$ & $I+9$ & $\mathrm{I}+9$ & $I+9$ & $I+9$ & - \\
\hline Anal fin rays & $\mathrm{II}+8$ & $\mathrm{II}+8$ & $\mathrm{II}+8$ & $\mathrm{II}+8$ & - \\
\hline Pectoral fin rays & $15-16$ & $15-16$ & $15-16$ & $15-16$ & - \\
\hline
\end{tabular}

$T L$ total length; $S L$ standard length; $P D_{1} L$ pre-first dorsal fin length; $P D_{2} L$ pre-second dorsal fin length; $P A L$ preanal fin length; $P P e l$ pre-pelvic length; $P P e c L$ pre-pectoral fin length; $H L$ head length; $D_{2} F L$ second dorsal fin length; $A F L$ anal fin length; $D @ D F 1$ depth at first dorsal fin origin; $D @ A F$ depth at anal fin origin; $P r O L$ preorbital length; $E D$ eye diameter

*Significant at $1 \%$ level of significance; different superscript across rows shows significant difference whereas same superscript shows no significant difference 
marginally smaller than eye diameter; pre-orbital length and eye diameter $6.9-8.4 \%$ and $10.1-11.3 \%$ of standard length; colour slivery grey to light pinkish; two dark longitudinal stripes on sides of the body (more prominent in smaller individuals); upper stripe narrow running from snout to upper margin of caudal peduncle; lower stripe broader from snout to centre of caudal fin passing through orbit; fins with light yellow or pink sheen.

\section{Distribution in Western Indian Ocean}

South Africa, Mozambique, Madagascar, Reunion, Mayotte, Seychelles along southwest Western Indian Ocean; Persian Gulf and Gulf of Oman along northwest Western Indian Ocean (Froese and Pauly 2018); Laccadive Sea along Southern western Indian Ocean (Jones and Kumaran 1980; Froese and Pauly 2018): Pakistan along Northern Arabian Sea (Psomadakis et al. 2015); off Maharashtra coast (ZSI 2012); off Gujarat Coast along northeast Arabian sea (present study; Fig. 1).

Prior to present investigation, presence of apogonids (as Apogon spp.) from the study region were regularly reflected in trawl bycatch reports or in gut content studies of predatory bottom-dwelling fishes (Zynudheen et al. 2004; Metar et al. 2005; Saker et al. 2013; Mali et al. 2017; Dash et al. 2018) but none of the ichthyofaunal diversity study from the region barring the study conducted by ZSI (2012) for Maharashtra, northwestern coastal state of India documents the species diversity of apogonids. As per ZSI (2012) only six species of apogonids namely Jaydia ellioti (Day, 1875), Ostorhinchus fasciatus (White, 1790), Pristiapogon fraenatus (Valenciennes, 1832), Lepidamia multitaeniata (Cuvier, 1828), Nectamia savayensis (Gunther, 1872) and Fibramia thermalis (Cuvier, 1829) were reported to occur in coastal waters of Maharashtra. A similar study conducted by ZSI (2000) for the state of Gujarat, India failed to document any species of apogonids from Gujarat. Hence the present study claims the first documented record of A. pseudotaeniatus, $J$. queketti and $J$. lineata from North East Arabian Sea (Northwest coast of India) and $O$. fasciatus from the coastal waters of Gujarat. A morphometric assessment of the four species recorded during the present study revealed a significant difference among them (Table 1). A. pseudotaeniatus was found to be the most divergent species in terms of morphometric attributes. Among the 12 evaluated morphometric ratios, only two were found to be similar among all the four species. Depth at 1st dorsal, pre-orbital length and anal fin grossly separate genus Apogonichthyoides from others with former being deeper. Pre-orbital length in $O$. fasciatus is similar to A. pseudotaeniatus but the former is having a much narrower body than the later. The two species of genus Jaydia resemble each other in several morphometric attributes but the prominent difference was observed second dorsal and anal fin length. Meristic characters do not offer much towards discrimination of the species. The morphological features like presence of spot or bands on the body and pigmentation of fins were mostly used for field identification of most of the species of apogonids. A filed key based on easily observable characters is presented below for all the nine species recorded from the region including both past and present studies for easy and prompt reporting of the species by the field enumerators working in the region.

1. (a) Horizontal or vertical bands or stripe on sides of the body 2

(b) No prominent bands on sides of the body .........6

2. (a) Horizontal bands or stripes on the sides of the body ................................................ 3

(b) Vertical bands or stripes on the sides of the body ................................................ 5

3. (a) Single horizontal stripe with basicaudal spot $\begin{array}{llllllllllllllll}\ldots & \ldots & \ldots & \ldots & \ldots & \ldots & \ldots & \ldots & \ldots & \ldots & \ldots & \ldots & \ldots & \ldots & \ldots & \ldots\end{array}$ .................... 4

(b) Double horizontal stripe running across the length of body without basicaudal stripe O. fasciatus

4. (a) Single horizontal stripe running across the length of body ................................ P. fraenatus

(b) Single horizontal stripe in the head region only

F. thermalis

5. (a) Numerous vertical bands (10-12) on sides of body ........................................... J. lineata

(b)Two vertical bands on body below 1st and 2nd dorsal fins with basicaudal spots ............ A. pseudotaeniatus

6. (a) 1st dorsal fin with prominent black blotch/marking .................................................. 5

(b)1st dorsal fin without prominent black blotch and upper caudal peduncle with dark saddle $\ldots . . . . N$. savayensis

7. (a) Prominent eyespot on the posterior part of 1 st dorsal fin ...................................... queketti

(b) Part of first dorsal fin with black marking but not in form of eyespot ................................ 8

8. (a) Anterior part of 1 st dorsal fin with prominent black blotch ................................. L. multitaeniata

(b) Upper half of 1 st dorsal fin with black color J. ellioti.

Acknowledgments The authors are thankful to the Director, ICARCMFRI, Director, ICAR-CIFE, and Head, Crustacean Fisheries Division, ICAR-CMFRI for facilitating the present study. The authors also wish to acknowledge fishermen of the region for sharing GPS records and providing bycatch samples for study. 


\section{Compliance with Ethical Standards}

Conflict of Interests The authors declare that they have no conflict of interest.

\section{References}

Allen G (1999) Apogonidae. In: Carpenter KE, Niem VH (eds) FAO species identification guide for fishery purpose. The living marine resources of Western Central Pacific. Vol. 4. Bony fishes part 2 (Mugilidae to Carangidae). FAO, Rome, pp 2602-2613

Dash SS, Chakraborty SK, Vivekanandan E, Zacharia PU, Jaiswar AK, Dash G, Bharadiya Sangita A, Gohel J (2018) Feeding habits of milk shark, Rhizoprionodon acutus (Ruppell, 1837) in the Gujarat coastal waters of north-eastern Arabian Sea. Reg Stud Mar Sci 17: $78-86$

Devi SM, Jaiswar AK, Chakraborty SK, Kumar R, Shirke S (2018) Species discrimination of clupeoid fishes (Pisces: Clupeiformes) from Andaman waters based on morpho-meristic characters. Indian J Mar Sci 47(01):141-147

Dutt S, Rao MPRR (1980) Apogon andhrae, a new species of apogonids fish from the bay of Bengal. J Nat Hist 14:743-748

Froese R, Pauly D (2018) Family Apogonidae retrieved from http:// www.fishbase.de/country/. Accessed 15 September 2018

Gon O (1986) Apogonidae. In: Smith MM, Heemstra PC (eds) Smiths' sea fishes. Springer-Verlag, New York, pp 546-561

Hashim M, Akhilesh KV, Pillai NGK (2012) Reports of Apogonichthyoides sialis (Perciformes: Apogonidae) from the west coast of India. Mar Biodivers Rec 5:1-3

Hubbs CL, Lagler KL (1958) Fishes of the Great Lakes region, 2nd edn. Cranbrook Institute of Science Bulletin, pp 1-332

Jones S, Kumaran M (1980) Fishes of Laccadive archipelago. The nature conservation and aquatic science service. Kerala, India

Joshi KK, Sreeram MP, Zacharia PU, Abdussamad EM, Varghese M, Habeeb Mohammed OM, Jayabalan K, Kanthan KP, Kannan K, Sreekumar KM, George G (2016) Checklist of fishes of the Gulf of Mannar ecosystem, Tamil Nadu, India. J Andaman Sci Assoc 58(1):34-54

Kumar R, Rahangdale S, Roul SK (2018) Filling missing links in albuneid crab distributions (superfamily Hippoidea) in the bay of Bengal, eastern Indian Ocean. Crustaceana 91(12):1495-1504

Mali KS, Vinod KM, Farejiya MK, Bhargava AK (2017) Food and feeding habits of two major lizardfishes (family: Synodontidae) occurring along northwest coast of India between lat $18^{0}-23^{\circ} \mathrm{N}$. Int J Life Sci Scienti Res 3(3):1039-1046
Marnane MJ (2001) The trophic role of cardinalfishes (family Apogonidae) on coral reefs. Dissertation, James Cook University, pp. 1-135

Metar SY, Chakraborty SK, Jaiswar AK, Telvekar PA (2005) Food and feeding habits of Saurida tumbil (Bloch, 1795) off Mumbai waters. J Indian Fish Assoc 32:141-148

Muddulakrishna N, Rao G, Suresh KM, Reddy RS (2015) A new record of cardinalfish Ostorhinchus fleurieu (Lacepede, 1802) from Middle East coast of India (Pisces: Apogonidae). Indian J Exp Zool 18(1): 39-41

Psomadakis PN, Osmany HB, Moazzam M (2015) Field identification guide to living marine resources of Pakistan. FAO, Rome, pp 334 335

Rajan PT, Sreeraj CR, Immanuel T (2013) Fishes of Andaman Andaman and Nicobar Islands: a checklist. J Andaman Sci Assoc 18(1):47-87

Ranjith L, Kannan K, Joshi KK, Vinod K (2016a) Range extension of the titan cardinalfish, Holopogon maximus (Boulenger, 1888) in the southern coast of India. Natl Acad Sci Lett 39(2):95-98

Ranjith L, Ramkumar S, Kannan K, Vinod K, Joshi KK, Shukla SP, Purushothaman CS, Chakraborty SK (2016b) Note on occurrence of Jaydia queketti (Osteichthyes: Apogonidae) from bycatch of tropical trawl fishery. Curr World Environ 11(2):604-609

Saker Y, Chakraborty SK, Jaiswar AK, Kumar P (2013) Food and feeding habits of Priacanthus hamrur from Mumbai, northwest coast of India. J Indian Fish Assoc 40:77-84

Saravanan R, Purushottama GB, Rohit P (2017) Diversity and distribution of cardinalfishes in Indian coastal waters with an occurrence report of spot fin cardinalfish Apogon queketti from central southwest coast of India. $4^{\text {th }}$ Indian Biodiversity Congress, Puducherry, India

Suresh GK (2007) Three new records of Apogonids (order-Perciformes, suborder-Percoidei) from Indian seas. J Mar Biol Assoc India 49(1): $105-108$

Vikas KR, Gangan SS, Jaiswar AK, Lal DM (2018) Taxonomic study of flatheads (family: Platycephalidae) occurring along the west coast of India. Indian J Mar Sci 47(05):1023-1028

ZSI (2000) State fauna series no. 8, fauna of Gujarat, part 1 (vertebrates). Zoological survey of India. Kolkata, India, pp $1-464$

ZSI (2012) State fauna series no. 20, fauna of Maharashtra, part 1 (vertebrates). Zoological survey of India. Kolkata, India, pp 1-464

Zynudheen AA, Ninan G, Badonia R (2004) Utilization of trawl bycatch in Gujarat (India). NAGA, WorldFish Center 27(3):20-23

Publisher's Note Springer Nature remains neutral with regard to jurisdictional claims in published maps and institutional affiliations. 